\title{
The Exception and the Rule: Fictive, Real, Critical
}

\section{Ulrike Kistner}

Walter Benjamin's famous statement in the eighth of his "Theses on the Philosophy of History," that "the state of [exception] in which we live is not the exception but the rule," has become as normalized as its proposition asserts. Few turns of phrase have become as easily convertible, turning the "special property" (of the definition of a Greek idioma) through collocation into an implicit signified conventionalized by common usage. In the phrases turning on the elements "the exception" and "the rule," the antonyms are being assimilated to each other, neutralizing their oppositional relation - not as a matter of a mystical "attraction of opposites," nor even as a matter of a special type of Schmittian complexio oppositorum, but rather, in Michael Marder's terms, ${ }^{2}$ as a matter of a "metonymic abuse of modernity." Without examining the antonymic relation between the terms, their specific figural emergence tends to be relegated to oblivion. This process of conventionalization is transported into the philosophical

1. Walter Benjamin, "Theses on the Philosophy of History," in Illuminations, trans. Harry Zohn (London: Pimlico, 1999), p. 248. I have changed Zohn's translation "state of emergency" here to the conceptually more accurate "state of exception."

2. "The metonymic abuses of modernity," in Marder's definition, designate systematic conflations symptomatic of political orders of modernity, in which distinct terms are being conflated, and in that conflation, acquire metonymic status, in which an element comes to stand in for the whole: "bourgeois legality metonymically signifies legitimacy in general, constitutional law and the Rechtsstaat constitution denote the constitutional regime as such, and the state appears as the incarnation of the political." Michael Marder, "In the Name of the Law: Schmitt and the Metonymic Abuses of Legitimacy," paper presented at the 2009 Telos Conference, available online at http://www.telospress.com/main/ index.php?main_page=news_article\&article_id=292. 
discourse in which these terms acquire further attributions. The semantic fields of "the exception" and "the rule" have provided fertile ground for such transpositions - prime examples being the phrases "the exception proves the rule" and "the exception has become the rule."

The idiomatic expression "the exception proves the rule," ostensibly assimilating the exception to the rule, is derived from the medieval Latin legal principle "the exception confirms the rule in cases not excepted" ("exceptio probat regulam in casibus non exceptiis"), which in turn traces its history to Cicero's defence of Lucius Cornelius Balbus (56 BC). ${ }^{3}$ Cicero reasoned: "If the exception makes... an action unlawful, where there is no exception the action must necessarily be lawful" ("Quod si exceptio facit ne liceat, ubi non sit exceptum, ibi necesse est licere").

Cicero's dictum demonstrates that in its initial legal formulation, exceptio designates an omission, taking a case out of the coverage of the rule. This is in contrast to the idiomatic phrase "the exception proves the rule," in which the exception is associated with the sense of something unusual, extraordinary. Thus, the idiomatic expression removes the legal principle from the domain of its initial application, and propels it along a slide toward another sense linked with the original one by way of an ambiguity.

It is that kind of slippage that plays itself out in the debates of the 1930s pertaining to constitutional law and political theory insofar as they subscribe to the similarly idiomatic and near-axiomatic expression "the exception has become the rule."

What interests me here is the longevity of a construction that recalls Schmitt's famous dictum opening his Political Theology, "Sovereign is he who decides on the state of exception," and links it with Benjamin's

3. Balbus had been awarded Roman citizenship for his service under Quintus Caecilius Metellus Pius and Pompey against Sertorius; he was friendly with Julius Caesar and became one of the chief financiers in Rome at the time of the formation of the triumvirate. His position as a naturalized foreigner, his influence, and his wealth made Balbus many enemies. He was accused of having been illegally granted Roman citizenship by the triumvirs. The prosecutor pointed out that treaties with some non-Roman peoples prohibited granting them citizenship and suggested this should be inferred in Balbus' case. Following Cicero's defence of Balbus, the latter was acquitted. After Caesar's murder in $44 \mathrm{BC}$, he gained the favor of Octavian; in 43 or $42 \mathrm{BC}$, he was praetor, and in $40 \mathrm{BC}$ he became the first naturalized Roman citizen to attain the consulship.

4. Carl Schmitt, Political Theology: Four Chapters on the Concept of Sovereignty, trans. George Schwab (Chicago: Univ. of Chicago Press, 2005), p. 5. 
eighth thesis, even as Schmitt's notion of sovereignty and the provenance of Benjamin's idea of the state of exception would contradict much of their present-day elaborations. In the latter-day revisions, sovereignty and state power appear as forces violently separating human life from its potentialities, to the point of exposing it to death. What has been excepted by the force of the exclusive inclusion of sovereignty has become a matter of rule, and of the rule. For this notion, Benjamin's eighth thesis is adduced as warrant.

Giorgio Agamben's Homo Sacer trilogy, published in the late 1990s, is the most recent and widely acclaimed reflection on this and related themes that have lost none of their fulcrum since their first formulations in the early 1920s, as the perplexities of the rights of man, the conundrums of statelessness and transnational citizenship, of constitution-making, of biopolitics and a new series of de-politicizations and re-politicizations are reopening the questions that exercised political and legal theorists in the shadow of faltering states and encroaching totalitarianism in the $1920 \mathrm{~s}$ and 1930s.

Agamben inflects Schmitt's (in)famous dictum biopolitically to posit an integral relationship between sovereignty and bare life. ${ }^{5}$ The power to make live and let die relies on two elements closely tied up with the definition of sovereignty: the decision and the exception.

Agamben investigates the exception in contemporary spaces of systematic lawlessness. He sees the permanency of the state of exception taking hold in the states of siege and exception ever since World War I, and particularly following in the wake of article 48(2) of the Weimar Constitution. The provisions for a state of exception, moving from wartime measures for dealing with internal disorder to political measures extending into the civil sphere, have become dominant techniques of governance. ${ }^{6}$ The state of exception is said not only to become the rule but to function as the "paradigm," practice, and technique of "normal" political rule.

Agamben makes of sovereignty a transhistorical continuum with its most consequential application and perturbing actualization in modernity,

5. Giorgio Agamben, Homo Sacer: Sovereign Power and Bare Life, trans. Daniel Heller-Roazen (Stanford, CA: Stanford UP, 1998), p. 6.

6. Giorgio Agamben, State of Exception, trans. Kevin Attell (Chicago: Univ. of Chicago Press, 2005), pp. 2, 5; see also p. 14.

7. See the title of the first chapter of Agamben's State of Exception; see also ibid., pp. 6-7, 13-14. 
from biopolitics through citizenship and its exclusions, to warfare, genocide, and mass violence beneath and beyond the state, to forced migration and interventions on humanitarian grounds, to nationalist and racist cultural logics, spatial exclusions, to lawless indefinite detention and particular governmental measures - in fact, the entire catalogue of twentieth- and twenty-first-century political calamities and perplexities. In Agamben's hands, these acquire planetary dimensions: the camp has become "the new biopolitical nomos of the planet."

At the very least and latest, the designation of homo sacer that renders indistinct the ways and states of being at the threshold - pertaining to victims and survivors of genocide, mass violence, sexual violation, subjects of medical experiments, comatose and neomort bodies, the Muselmann, individuals and populations relegated to a status of being "superfluous," detention-center inmates reduced to naked life, refugees, and the inhabitants of the "third world" - should alert us to the need to critically examine how slippages and conflations come about, whether theoretically, ideologically, politically, legally, or policy-wise. Similarly, the designation as spaces of exception of phenomena as diverse as Nazi concentration and death camps, refugee camps, detention centers for "illegal immigrants," ghettos, and airports, should make us prick up our critical eyes and ears.

It turns out that Agamben can arrive at this construction only through a reading in several aspects diametrically opposed to Schmitt's genealogy of sovereignty. The concept of sovereignty and the decision on the state of exception are not, for Schmitt, ipso facto complicit with encroaching totalitarianism, but potential barriers against it. ${ }^{9}$

What Schmitt calls "sovereign" clearly refers back to his definition of sovereign dictatorship in Die Diktatur, concerning the case in which the entire constitutional order is in question, rather than simply the arrogation of extralegal powers enacted as specific draconian measures by a commissarial dictator. Without being able to rely on the existing constitution, it entails convening a constitutive body upon the (revolutionary) suspension of the entire existing constitutional order, in order to found a new one that cannot be derived from, authorized, or legitimated by the previous one

8. Agamben, Homo Sacer, p. 176.

9. Aspects of the elaborations in the last four paragraphs first appeared in Ulrike Kistner "Sovereignty in Question: Agamben, Schmitt, and Some Consequences," SA Public Law 24, no. 2 (2009): 250-52. 
in any way. ${ }^{10}$ Prime examples of sovereign dictatorships for Schmitt are the self-constitution of the people in the wake of the French Revolution ${ }^{11}$ and the democratically elected national constituent assembly that came together in Weimar in $1919 .{ }^{12}$ After 1920, the only possible exemplar of a sovereign dictatorship is provided by the Marxist vision of the dictatorship of the proletariat. ${ }^{13}$

In a commissarial dictatorship, on the other hand, powers are delegated to the commissar as situationally specific and spatially/temporally limited measures deemed requisite to realize the law. The commissar is subject to instructions issued to him by his taskmaster. He cannot create a new state of law. ${ }^{14}$

Conceptually, these two types of dictatorship are incommensurable, discontinuous, and mutually exclusive. The minute the constituent assembly has completed its task and the constitution becomes the prevailing framework of law, the terms of reference that a sovereign dictatorship

10. Carl Schmitt, Die Diktatur: Von den Anfängen des modernen Souveränitätsgedankens bis zum proletarischen Klassenkampf (Berlin: Duncker \& Humblot, 2006), p. 134. See also Carl Schmitt, Constitutional Theory, trans. Jeffrey Seitzer (Durham, NC: Duke UP, 2008), pp. 131-32.

11. Schmitt, Constitutional Theory, p. 50; also p. 127.

12. Ibid., pp. 108, 109; also pp. 143-44.

13. This vision was first formulated by Marx in his famous letter to Joseph Weydemeyer of March 5, 1852: "Now, as for myself, I do not claim to have discovered either the existence of classes in modern society or the struggle between them. Long before me, bourgeois historians had described the historical development of this struggle between the classes, as had bourgeois economists their economic anatomy. My own contribution was (1) to show that the existence of classes is merely bound up with certain historical phases in the development of production; (2) that the class struggle necessarily leads to the dictatorship of the proletariat; [and] (3) that this dictatorship, itself, constitutes no more than a transition to the abolition of all classes and to a classless society" (Karl Marx and Frederick Engels, Selected Correspondence [Moscow: Foreign Languages Publishing House, n.d.], p. 86.) In his 1931 article "Die staatsrechtliche Bedeutung der Notverordnung," Schmitt notes (in an endnote): "The so-called dictatorship of the President of the Reich provided for by Art. 48, para. 3 [of the Weimar Constitution] was clearly a typical case of a commissarial dictatorship. But in no instance of the presidial system could it be called a sovereign dictatorship. A sovereign dictatorship would have hardly found an effective kind of legitimacy on any other basis than that of a philosophy of history; but at the time, this was still the firmly asserted prerogative of Marxism" (Carl Schmitt, "Die staatsrechtliche Bedeutung der Notverordnung, insbesondere ihre Rechtsgültigkeit," in Verfassungsrechtliche Aufsätze aus den Jahren 1924-1954: Materialien zu einer Verfassungslehre [1958; Berlin: Duncker \& Humblot, 2003], p. 261, my translation).

14. Schmitt, Die Diktatur, pp. 33, 34, 55, 133, 134, 247. 
gives itself cease to operate. ${ }^{15}$ While the commissarial dictatorship can become included within the legal order and the commissar can become a regular civil servant, the reverse is not possible: the legitimacy of constituent power within the framework of a sovereign dictatorship is in principle irreducible to legality.

While referring to Schmitt's distinction between sovereign and commissarial dictatorship, Agamben disregards it for his further investigations, simply rejecting any theories that posit the state of exception in relation to the system of law. ${ }^{16}$ For Agamben, such theories have the dubious claim and aim of justifying the suspension of the law and the creation of domains of anomie, ${ }^{17}$ as well as inscribing the state of exception within a legal context. ${ }^{18}$

Agamben casts Schmitt's carefully drawn distinction between sovereign and commissarial dictatorship as two stages along a continuum. ${ }^{19}$ This continuity is extended to posit a fluid transition from the Weimar Constitution to the Nazi seizure of power. ${ }^{20}$ In the early 1930s, Agamben contends, the Weimar Republic had degenerated into a regime of a state of exception. For then as for now, Agamben perceives the "danger [of] a transformation of a provisional and exceptional measure into a technique of government." 21

15. Ibid., pp. 236, 237.

16. Agamben, State of Exception, pp. 50-51.

17. Ibid.

18. Giorgio Agamben, "State of Exception," Make World Festival 2003, paper 3, available online at http://www.makeworlds.org/node/16.

19. Agamben, State of Exception, p. 32. The confounding of this distinction is paralleled by another, less explicit move. While Agamben draws a conceptual-historical lineage of the state of exception and shows Schmitt's and Benjamin's reliance on the distinction between real and fictive states of emergencies drawn by Theodor Reinach in his De l'état de siège: étude historique et juridique (1885), he reduces Schmitt's typology of the state of exception to a simple opposition between "fictive" and"real" (see Agamben, State of Exception, p. 3), equating the real state of exception with a military action, which was taken over into police measures to curb internal unrest upon the creation of a juridical vacuum, and a fictive state of exception with a political one (ibid., p. 5). Agamben implicitly accepts Rossiter's proposed revision (in the latter's Constitutional Dictatorship: Crisis Government in the Modern Democracies [New York: Harcourt Brace, 1948]) of Schmitt's distinction between sovereign and commissarial dictatorship, to the effect of abolishing the substantive distinction between them and arranging them on a continuum, making sovereign dictatorship the graduated effect of a commissarial dictatorship gaining permanence (see Agamben, State of Exception, p. 9; see also p. 6).

20. Agamben, State of Exception, pp. 15, 34; see also p. 6.

21. Agamben, "State of Exception." 
Schmitt explicitly refutes the idea of a gradual transition from the commissarial dictatorship of Weimar to the supposed sovereign dictatorship of Nazi totalitarianism by pointing out that the legalization of commissarial measures is anything but an indication of a transition toward a revolutionary dictatorship or of any principle of state formation; rather, it is simply an attempt at protecting the prevailing constitution against failures of its law-giving role. ${ }^{22}$

While not endorsing the interventions that limit personal rights and freedoms of citizens who happen to fall into the ambit of such commissarial measures - interventions that he calls "horrific" 23 -Schmitt sees the problems elsewhere: the commissarial dictatorship, in which the commissar temporarily carries out a task commissioned by an ordinance addressing situationally specific requirements that cannot by the same token attain the status of a new legal order, ${ }^{24}$ is being drawn into the state of law. ${ }^{25}$ A second problem arises as the negative definition of exemption from protection by rights is being turned into the bestowal of positive powers on the commissar. ${ }^{26} \mathrm{~A}$ third problem arises from the exclusions specified in the exception that limit the powers of the sovereign: ${ }^{27}$ the basic rights suspended in the exception are so general that the power delimiting them does not itself become circumscribed, ${ }^{28}$ thus opening the door to opportunism and extralegal excesses. ${ }^{29} \mathrm{~A}$ fourth problem concerns the converse effect: the powers of the president as guardian of the constitution are being limited through the minutely detailed listing of a multiplicity of provisions that can be suspended either in toto or in part.

These four specific problems are related to broader ones that Schmitt outlines in Constitutional Theory, published in 1928. According to Schmitt, the constitution of the state in its political unity becomes relativized through being confused and substituted with a multiplicity of laws, norms, and regulations to such an extent that any particularist concern,

22. Schmitt, "Die staatsrechtliche Bedeutung der Notverordnung," p. 260.

23. Schmitt, Die Diktatur, p. 10.

24. Ibid., p. 33.

25. Ibid., p. 196; see also Schmitt, "Die staatsrechtliche Bedeutung der Notverordnung," pp. 237, 239.

26. Schmitt, Die Diktatur, p. 195.

27. Ibid., pp. 195, 199, 213.

28. Ibid., p. 213.

29. Ibid. Elaborations in this paragraph first appeared in Kistner, "Sovereignty in Question," p. 254. 
when supported by party-political or other sectional interests, can become legalized and attain the force of constitutional law. ${ }^{30}$ More generally, the lack of insight into the nature and role of constitutional law renders the latter vulnerable to manipulation by immediate and particularist interests. ${ }^{31}$

The conflation of the constitution and constitutional law attained a systematic character in the Weimar Constitution itself, with its combination of elements of sovereign and commissarial dictatorship..$^{32}$ On the one hand, it enshrined an understanding of a sovereign constitution as an expression of a political unity; on the other hand, it relativized itself as an expression of political unity by laying down procedures for changing particular provisions. ${ }^{33}$

It thus emerges that Agamben and Schmitt accord different meanings to the state of exception. While Agamben sees in the Nazi seizure of power the intensification of a commissarial dictatorship turned sovereign, Schmitt, in his writings of the early 1930s (up to 1933), pinned his (spectacularly misplaced) hopes on the Reichspräsident's (commissarial) declaration of a state of exception to protect the constitution from its own fragility and to prevent the Nazi seizure of power. ${ }^{34}$ While Agamben sees Weimar's peculiar "protected democracy" as a constitutional dictatorship that facilitates a sliding transition to a totalitarian regime, Schmitt asserts a qualitative difference between dictatorship and totalitarianism. ${ }^{35}$ Moreover, Schmitt draws a dividing line between the Weimar Constitution and the National Socialist regime. ${ }^{36}$

30. See Schmitt, Constitutional Theory, pp. 72-73.

31. Schmitt, Die Diktatur, p. 221.

32. Ibid., p. 200.

33. Schmitt, Constitutional Theory, pp. 105-6; see also Schmitt, "Die staatsrechtliche Bedeutung der Notverordnung," p. 239.

34. In fact, Schmitt supported Chancellor Kurt von Schleicher "in his attempt to prevent a Nazi acquisition of power in January 1933, by instituting an Ausnahmezustand and banning both the Nazi and Communist parties" (Joseph W. Bendersky in Carl Schmitt, On the Three Types of Juristic Thought, trans. Joseph W. Bendersky [Westport, CT: Praeger, 2004], p. 15).

35. Extrapolating from Schmitt's first "Nazi" work, Staat, Bewegung Volk, Hannah Arendt characterizes totalitarianism as a movement dissolving the state. See Hannah Arendt, The Origins of Totalitarianism (New York: Harcourt, 1994), p. 266.

36. Carl Schmitt, Staat, Bewegung, Volk: Die Dreigliederung der politischen Einheit (Hamburg: Hanseatische Verlagsanstalt, 1933), pp. 5, 6. Elaborations in the preceding paragraph first appeared in Kistner, "Sovereignty in Question," p. 255. 
Nazi totalitarianism is entirely novel. It is consonant neither with the criteria of a commissarial dictatorship nor with those of a sovereign dictatorship.

Commissarial dictatorships tend to become integrated into the system of law-which is not the case under National Socialism. A commissarial dictatorship entails the mandatory preservation of the existing political and legal order and the consent and control of parliament. Schmitt explicitly distinguishes the delimited measures of a commissarial dictatorship in a state of exception from totalitarian measures, pointing out that "an absolutist ruler, a ruler within a totalitarian system, does not need constitutional provisions for a state of exception." ${ }^{37}$

Far from being temporally, spatially, and situationally circumscribed, and far from tending to be integrated with legal provisions of a state of law, ${ }^{38}$ a flurry of special ordinances remains characteristic of the totalitarian regime that exercises its powers through being continuously in flux, ${ }^{39}$ with the state becoming "state-bearing party" under a "state-and-peoplebearing leadership" becoming "state- and-people-bearing movement" in that "tripartite political unity" 40 of Schmitt's Staat, Bewegung, Volk-the

37. Schmitt, "Die staatsrechtliche Bedeutung der Notverordnung," p. 260.

38. This would be the case in the actualization of legal positivism decried but admitted by Schmitt for the Weimar period. Legal positivism refers the legislative to the executive, thus legalizing the state of exception. In relation to the state of exception, in particular, such legalization is taken out of political contestation and integrated into police operations. See Günter Frankenberger, Staatstechnik: Perspektiven auf Rechtsstaat und Ausnahmezustand (Berlin: Suhrkamp, 2010), p. 91.

39. In 1933, Schmitt enthusiastically embraces this state of flux of the "Staat- und Volktragende Bewegung" as "the political element of the community": "the dynamic motor as opposed to the static element of the civil service apparatus that has to rely on norms and their corresponding political decisions" (Schmitt, Staat, Bewegung, Volk, p. 17).

40. Schmitt explains: "The new state structure is marked by the fact that the political unity of the people, and thereby, all the regulation of its public life, appear to be ordered in three distinct series. The three series do not run parallel one to the other, but one of them, the Movement, which carries the State and the People, penetrates and leads the other two. Three formations move side by side, in their own order, meet in certain decisive points, particularly at the apex, have distinctively different contacts and direct links with each other, which however are not allowed to cancel the distinctions, and as a whole, effected by the carrying series, all shape the constitution of the political unity.... Each of the three words: State, Movement, People, may be used alone to denote the whole of the political unity. At the same time, however, it indicates yet another particular aspect and a specific element of this whole. In this way, the State may be regarded strictly as the politically static part; the Movement as the dynamic political element, and the People as the apolitical side, growing under the protection and in the shade of the political decisions" (Carl Schmitt, 
treatise that marks his turn to Nazi power and ideology, a text as troublingly programmatic as it is sharply diagnostic. After the war, Schmitt extends his earlier diagnosis: the Nazi power structures defied any description of an ordered and predictable division of competencies, while adhering to bureaucratic procedures. ${ }^{41}$ The semblance of legality had been stretched thinly to cover a host of special ordinances and singular decrees distinct from exceptional measures of a commissarial dictatorship. The special ordinances marking a personalized "leadership principle" (Führerprinzip), ${ }^{42}$ which Schmitt calls "deliberate subjectivism" (absichtlicher Subjektivis$m u s$ ), institutionally cemented through "Personal-Unionen" uniting the organizationally distinct top levels of decision-making, ${ }^{43}$ constitute one of the unprecedented distinguishing characteristics of this regime, ${ }^{44}$ which relegated the executive powers unfolding under such subjectivism out of public scrutiny, control, and any regularity or predictability. ${ }^{45}$ The irreconcilability between the powers of the commanding heights, themselves at odds with each other, and any semblance of a legal order (never mind legitimacy) formed the systematic asystematicity on which this totalitarian regime turned.

The Nazi seizure of power does not fall under the definition of a sovereign dictatorship either, as it does not suspend the entire constitutional order in order to found a new one; it does not act as legitimate, sovereign, constituent power. ${ }^{46}$

State, Movement, People: The Triadic Structure of the Political Unity (1933), ed. and trans. Simona Draghici [Corvallis, OR: Plutarch Press, 2001], pp. 11-12).

41. Carl Schmitt, "Der Zugang zum Machthaber, ein zentrales verfassungsrechtliches Problem," in Verfassungsrechtliche Aufsatze aus den Jahren 1924-1954: Materialien zu einer Verfassungslehre (Berlin: Duncker \& Humblot, 2003), p. 431.

42. Ibid., p. 434.

43. Schmitt, Staat, Bewegung, Volk, p. 20.

44. Schmitt, "Der Zugang zum Machthaber," p. 436.

45. See also Schmitt's positive embrace of such powers and inner-party sanctums in Staat, Bewegung, Volk, pp. 21, 22.

46. This is evident also in the peculiar status of the Enabling Act (Ermächtigungsgesetz) of 1933, which is a juridical anomaly: while the popular will expressed on March 5, 1933, in the plebiscitary vote of the Reichstagswahl (with a two-thirds majority) and confirmed in the municipal elections of March 12, voted for Adolf Hitler as Führer, the Enabling Act functioned as a transitional, interim constitution. At the time, Schmitt justifies this "transition" by reference to the very legalism (at the expense of legitimacy) that he had decried a year earlier, in his sharply critical Legality and Legitimacy. Simultaneously, Schmitt asserts the qualitatively new and unprecedented character of the new regime- but not by reference to a sovereign dictatorship, but to a simple self-abolishing negation: “... it 
The problem of totalitarianism, for Schmitt, lies neither in sovereignty nor in the decision on the state of exception per se. It resides somewhere else altogether. The Reichstag could not achieve the required simple majority, so it could issue decrees to the government without, however, being able to control their implementation. This incapacity has a long history that Schmitt outlines in various writings published during the 1930s. That history is one of the becoming-immanent of sovereignty, of the state, of Recht (as system of law), of considerations of justice, and of sources of authority and legitimacy. In this case, Schmitt talks of "the social complex" being rendered total, jeopardizing the formation of political unity under the ascendancy of economic polycracy and ideology. ${ }^{47}$ In tandem with this "becoming-immanent of sovereignty and of the state" goes a thorough-going depoliticization. As Recht, the state, authority, justice, and legitimacy are reduced to legalistic formality and function in the wake of nineteenth-century "legal positivism," Schmitt avers, the possibility of resistance, dissent, and disobedience is ruled out as "illegal," tendentially leading to the exclusion of any declared opponent or dissenter from the democratic homogeneity of "the people." ${ }^{\text {" }}$ Legal rulings gain the upper hand over other spheres of authority of the state.

The fact that exceptional "measures" (Maßnahmen) attained the force of law on numerous occasions in the Weimar Republic leading up to the Nazi seizure of power, is not, for Schmitt, related to the simple fact of the state of exception invoked on those occasions, as Agamben would have it. ${ }^{49}$ Rather, it is related to the fact that article 48 of the Weimar Constitution introduces a new and heterogeneous element: it conflates and confuses the role of an exceptional legislator (endowed with the power

is not without merit that a system surrenders on its own, in conformity with its own legality, and affixes its seal on its own end. But that is only the abdication and the death statement of the old law, and not the substantial definition of the new. Neither the base, nor the boundary or any essential interpretative opinion, that might bind the present-day State, can be deduced from the old era which has resigned. For the law in force nowadays, the 'empowerment' of 24 March 1933 is nothing but a kind of republican analogy to the explicit release from the oath of loyalty uttered by a monarch when renouncing the throne or abdicating. On this point, that legalization is in its juridical and political meaning what the legalistic mentality of a legislative liberal-democratic State is for the principle of loyalty in a State of monarchical servants" (Schmitt, State, Movement, People, pp. 6-7).

47. Carl Schmitt, Der Hüter der Verfassung (Berlin: Duncker \& Humblot, 1996), p. 90.

48. Ibid.

49. Agamben, State of Exception, p. 6. 
of suspending the law) with that of a the lawgiver - parliament - of the legislative state (Rechtsstaat), endowed with the power of giving the law and protecting fundamental rights, ${ }^{50}$ with the former trumping the latter; and it confuses measures to be taken to address very specific cases, with the general character of the law. These conflations and confusions produce multiple contradictions. Principal among them is the fact that the very measures adduced to defend the democratic constitution are those that can lead to its demise. ${ }^{51}$ As laws become a matter of the decision of the majority in parliament, even the dissolution of parliament itself, amounting to a coup d'état, would be called "legal." The party commanding $51 \%$ of the vote could legally enter into the state, and then close the door of legality through which it entered, to render the rest of the $49 \%$ illegal; it could relegate its party-political opponents to the status of common criminals, ${ }^{52}$ and it could destroy the constitutional system that had afforded it entry into the state.

Considering these entirely different and contrasting understandings and invocations of the state of exception, we should be able to discern entirely different meanings of variations of the same phrase- " the state of exception has become the rule" - being bounced around variously by Schmitt, Benjamin, and Agamben.

When Agamben says, "in our age, the state of exception comes more and more to the foreground as the fundamental political structure [i.e.,

50. Carl Schmitt, "Legalität und Legitimität," in Schmitt, Verfassungsrechtliche Aufsätze aus den Jahren 1924-1954, pp. 325-26; see also Schmitt, Der Hüter der Verfassung, pp. 125-26.

51. Schmitt, "Die staatsrechtliche Bedeutung der Notverordnung," p. 333. This notion of Schmitt's turned out to be prescient if considered in the light of the events surrounding the Machtergreifung. After the Reichstag fire on February 28, 1933, the government of Adolf Hitler received emergency powers from President Paul von Hindenburg under article $48(2)$ of the Weimar Constitution. Hitler used the commissarial powers granted to him to deprive Hindenburg and his supporters of all further powers.

52. Schmitt, "Legalität und Legitimität," p. 286. This only too real possibility undoes the history of sovereignty to that date, ultimately abolishing it. For it had been precisely through the introduction of the principle of sovereignty into the definition of the state in the aftermath of the confessional wars of the sixteenth and seventeenth centuries that the notion of "the enemy" was de-theologized and decriminalized to constitute a juridical category (to which effect the sovereign had to pronounce a decision on the question of justus hostis or justa causa of the hostile intention), thus paving the way for mutual recognition of sovereign states as equals in war, for subjecting war to regulations, and for concluding peace treaties. See Schmitt, The Nomos of the Earth in the International Law of the Jus Publicum Europaeum (New York: Telos Press Publishing, 2006). 
that of the sovereign decision over life and death] and ultimately begins to become the rule," he implies, empirically speaking, that the politicization of bare life now regularly reveals the sovereign decision. When Schmitt, in his writings before (and including) 1934 says, "the state of exception becomes the rule," he means, theoretically and genealogically speaking, ${ }^{53}$ that the legal-constitutional order under the sign of sovereignty has been eclipsed in being subsumed under legalistic rule and function, where it becomes subject to party-political and other sectional interests.

Benjamin's eighth thesis from his "Theses on the Philosophy of History" closely follows Schmitt's reflections on the relationship between different definitions of dictatorship as state of exception. The state of exception that is the rule encapsulates the definition of the state of exception invoked in combatting an external enemy and suppressing internal unrest. For Schmitt, this designates the ideal normal case (idealer Normalfall), revealing the core function and power of the system of law and the state. ${ }^{54}$ In this formulation, the state of exception does not pose particular theoretical problems. The state of exception becomes a philosophical problem only with the uncoupling of state and law from the system of law, in cases where the system of law cannot safeguard society. In that instance, "law flows into politics and history," from the contested political order to a "real state" whose legitimation cannot be found in an existing political or constitutional norm, but can only be envisaged in and through a philosophy of history. ${ }^{56}$

53. "The state of exception," for Schmitt, is a concept of Staatslehre, not simply a state of emergency (Schmitt, Political Theology, p. 5).

54. Schmitt, Die Diktatur, p. xviii.

55. Ibid.

56. Ibid., pp. xvi-xvii. The parallels between Benjamin's eighth thesis and Schmitt's conceptual distinctions in elaborating the definition and forms of dictatorship as state of exception emerge from a reading of Schmitt's densely packed preface to the first edition of Die Diktatur (1921): “A state of siege is called a dictatorship because of the suspension of provisions positively enshrined in the Constitution. From a revolutionary perspective, in contrast, a dictatorship refers to the entire existing order, thus transforming the concept [of dictatorship] from the legal system of the State to the Political. A further change in the concept of dictatorship is indicated where, as is stated in the literature of Communist provenance, not only the combated political order, but even the envisaged political order itself is called 'dictatorship.' In that case, the political actors use the term 'dictatorship' to designate their own state in its entirety, because it is taken to mean the instrument used to bring about a transition to a real state. Its legitimacy, however, consists in a norm that is no longer simply political or positively constitutional, but emanates from a philosophy of history. This is what makes of 'dictatorship'-because as exception it remains functionally 
While concurring on the same phrase, "the state of exception has become the rule," the effects of Schmitt's and Agamben's analyses are vastly different. While Agamben sees sovereignty proliferating in every arena of social life - in the figures of the doctor, the scientist, the expert, the priest, the migration official, the police officer acting with ill-defined powers or acting outside or beyond his powers, the securocrat, the militia man, the humanitarian agent, the warlord, the genocidaire, the agent of informal justice - it has receded for Schmitt. In precisely the figures in which it appears in exemplary form for Agamben, it is conspicuously absent for Schmitt. ${ }^{57}$

Yet, in a peculiar way, these opposing positions have inverse theoretical effects, not only in relation to each other, but in the relationship between their own terms and tenets. While Agamben's analysis purports to expose the biopolitical nucleus and nexus of sovereignty, and to demonstrate the proliferation of petty sovereigns in every area of social life, and thereby appears to place political power center-stage, it produces the reverse effect

dependent on what it negates - likewise, a category in philosophy of history" (Schmitt, Die Diktatur, pp. xvi-xviii, my translation).

57. A parallel argument can be construed that would illustrate along similar lines the difference in the analyses of Arendt and Agamben. While Agamben observes the politicization of bare life through the fact that life is drawn, in an inclusive exclusion, into the realm of the political, Arendt remarks on the depoliticization of the erstwhile hedged space of the political, which she understands as the invasion of the political by the social, expanding and overarching the once delimited space of the political (see Jürgen Brokoff, "Gesellschaftlicher Antisemitismus und romantische Geselligkeit: Hannah Arendts Kritik des Gesellschaftsbegriffs und der klassische Begriff des Politischen," in Hannah Arendt und Giorgio Agamben: Parallelen, Perspektiven, Kontroversen, ed. Eva Geulen, Kai Kauffmann, and Georg Mein [Munich: Wilhelm Fink, 2008], p. 244). Social anti-Semitism exemplifies the disappearance of the political and, as such, paves the way for the genocide perpetrated against the European Jewry. More broadly speaking, social anti-Semitism is an indication of the political drifting into the social, where it becomes indistinct. It is the expansion and intrusion of the social into the realm of the political that, for Arendt, effects an indistinction between the social and the political (see Hannah Arendt, The Human Condition [Chicago: Univ. of Chicago Press, 1973], p. 41), and effectively means a loss of world for political actors. One of the factors creating a "zone of indistinction" for Agamben, in contrast, lies in state of exception - that sovereign decision par excellence-aligned with the law in such a way that "the law maintains itself in relation to the exception in the form of its own self-suspension" (Giorgio Agamben, The Time That Remains: A Commentary on the Letter to the Romans, trans. Patricia Dailey (Stanford, CA: Stanford UP, 2005), pp. 104-5), in an inclusive exclusion, a seizing into the law of its outside. This is what neither Schmitt nor Arendt had in mind. The elaborations of the preceding six paragraphs first appeared in Kistner, "Sovereignty in Question," pp. 256-59. 
insofar as his assertions register, and in their own statement confirm, a thorough depoliticization. For Agamben, modern governmentality draws biological life fully within its realm, without critical remainder or excess. Agamben's own analysis contributes to this depoliticization by choosing to ignore the issue of constituent power in reducing the "sovereign dictatorship" of Schmitt's definition to the continuation and culmination of the special measures within a repressive state of exception.

Schmitt, too, has to concede the historical transformations of the state that have effectively drawn the state into society and that would necessitate a change in the conceptualization of the political. ${ }^{58}$ Yet Schmitt comes up with a more nuanced account of re-politicizations in the wake of sweeping processes of de-politicization upon the disappearance of historical anchors of sovereignty. Instead of relying on a transhistorically projected and retrojected monolithic idea of sovereignty, he investigates re-politicizations in the process of the drawing of the state into society, and expanding social power, through the phenomena of what he calls "apocryphal acts of sovereignty," and through the concept of polycracy coined by Johannes Popitz. "Apocryphal acts of sovereignty" are defined as social power complexes arrogating to themselves the powers of sovereignty in making themselves the agents of political will formation and its enforcement. ${ }^{59}$ "Polycracy" designates a multiplicity of legally autonomous agencies in the economy and finance sectors installing themselves at the local level, whose operations, often propagated under the motto of "self-government," extend independently of and beyond policy and legislation, ${ }^{60}$ splitting and destroying the frameworks provided by the state. In Franz Neumann's terms, the novel phenomenon of "the conjunct body of independent public agencies (social-insurance institutions, control boards, publicly owned corporations, and so forth), [that is] subject to no parliamentary supervision, has destroyed the unity of political decisions." ${ }^{61}$ While attributing

58. Schmitt, Political Theology, p. 63.

59. In the formulation of Schmitt's December 1927 preface to Constitutional Theory: "The treatment of the concept of sovereignty has suffered the most under this method of fictions and of disregarding specific circumstances. In practice, then, the habit of apocryphal acts of sovereignty develops. It is characteristic of this practice that state authorities and offices, without being sovereign, nevertheless occasionally and under tacit acceptance implement acts of sovereignty" (Schmitt, Constitutional Theory, p. 55).

60. Schmitt, Der Hüter der Verfassung, p. 71.

61. Franz Neumann, Behemoth: The Structure and Practice of National Socialism, 1933-1944 (New York: Octagon Books, 1963), p. 44. 
this notion of "polycracy" to "the National Socialist professors' ... charges against liberalism and democracy," ${ }^{\prime 2}$ and distancing himself from their "anti-democratic analysis, designed to minimize the meaning of fundamental rights," ${ }^{63}$ Neumann himself, in addressing the question, "If the National Socialist structure is not a state, what is it?" ${ }^{64}$ tentatively invokes the notion of an uncoordinated polycracy:

[W]e are confronted with a form of society in which the ruling groups control the rest of the population directly, without the mediation of that rational though coercive apparatus hitherto known as the state. ${ }^{65}$

While such developments dissolve the link between norm and validity, and limit the question of sovereignty to moments of political crisis, Schmitt is not prepared to sacrifice the concept of the political to an immanentist account of the state. He retains the definition of sovereign dictatorship as reference point and horizon for a genealogy of the state and a legal order, and at the same time as a normative condition for the possibilities of constitution (as constituent power) and critique.

The attribute "sovereign" remains central to constituent power, beyond historically located sovereignty and beyond sovereignty tied to the state. The challenge of thinking a concept of history in keeping with the insight that the state of exception has become the rule is met by Schmitt with the reinstatement of sovereignty in a particular sense - and that is where Schmitt and Benjamin envision the "real" state of exception. The new envisaged political order that cannot be derived from or legitimated by the existing one, can find its legitimation only in a norm posited by analogy with a future order whose vision is drawn from the philosophy of history (which Schmitt calls "real"). ${ }^{66}$ In this "miraculating" idea of constituent power lies the crux of Schmitt's early definition of sovereign dictatorship and the state of exception that it precipitates. And this is clearly the "real" state of exception toward which Benjamin's eighth thesis gestures.

To return to the contrasting analyses of the state and of sovereignty between Schmitt and Agamben, then, we could say that on Agamben's

62. Ibid., p. 42.

63. Ibid.

64. Ibid., p. 470.

65. Ibid.

66. Schmitt, Die Diktatur, p. xvi. 
analysis, petty sovereigns are proliferating everywhere in the world today, whereas for Schmitt, sovereignty is receding in society, while the need to call it to thought - and with it, to the reconstitution of the political-is becoming ever more urgent. ${ }^{67}$

67. The elaborations in this last paragraph first appeared in Kistner, "Sovereignty in Question," p. 265. 